\section{If They Only Had the Words: What Boys Would Tell Us About Reading}

\section{Michael Sullivan}

D o you ever wonder how to reach boys with books? Sometime, stop and listen to what they have to say.

You don't make girls read the books that I like, so why do you make me read the books the girls like?

Teachers sometimes think they are assigning a "boy book", when in reality they are not and therefore often miss the mark. It is important to understand that while some books have appeal to many boys, they are not the books that truly speak to boys. How often is a class assigned to read a real high fantasy book, or a piece of gothic horror, or even a high-action sports book? Indeed, how often is a nonfiction book assigned in an English class? Is there no language in nonfiction? The "boy books" assigned are usually just novels with boy characters.

When a classroom teacher plans a reading project or assignment one might question why it is that nearly always they assign a whole class to read a single book, and then spend countless hours trying to get students to discuss it? That formula is familiar; it is exactly the way most adult book clubs operate. The whole group reads the same book, usually an assigned novel and then everyone sits in a circle and discusses the book (well maybe everyone). Discussions center on character development and themes, which seems natural given the sedentary, collaborative nature of the setting. But look around at most book groups. The vast majority of adults that participate are female. The only difference between a "standard book club" and a class discussion is that the book club is voluntary. On the other hand in the classroom setting it is most often the case that boys and girls are forced to join the class discussion without any choice or input as to the type of book or the format of the discussion. It stands to reason that if men do not flock to the book club format why should we expect boys to be inspired by it?

I believe that boys would be better served if everyone in the class were required to read a book of their own choosing, then invited to report to the class what they chose and why they liked it or disliked it. Not only would the individual boy be able to read and express his valuation of his own reading, but then every boy in the class would have a multitude of choices recommended by his peers.

I wish I liked reading all the boring words that people say in your books, but I'm stupid so I don't.

There are reasons why boys do not like the types of books we give them. Psychologically, boys tend to be external thinkers, where girls tend to be internal thinkers. According to an article published in the Journal of Educational Psychology, Pomerantz, Altermatt, and Saxon (2002) girls look for the universal in themselves; boys look for themselves in the universe. Practically, that means that girls tend to feel a connection to the world around them. Boys do not. Indeed they need to forge that connection experientially. Girls will tend to see the world as operating on interpersonal cooperation and communication. Boys see the world on the Home Depot principal: rules and tools. Boys seek to understand the way the world works and how to manipulate those rules to get something done. While we generally accept these differences, we seldom think about how these differences will affect what boys read, how boys read, and how we should promote reading to boys. When we fail to make these distinctions, we promote a single view of what good reading is, and that single view is heavily colored by the fact that most educators are female. Boys see that what they want to read is not "good" or "real" reading, and assume that it is their own failing.

First, we must realize that the novel form, with its central character (protagonist) working through an internal issue with the help and intervention of other characters until he comes out a better person in the end, often has little appeal to boys. This is an internal looking theme more appropriate to the world view of girls. Boys will be drawn to the action, the plot, of a story and the real-life elements that help them to understand their world. Many boys that resist other types of reading will be drawn to fantasy and science fiction because these forms are inherently outward thinking, with characters that must go out into the world to find their place. They understand themselves through experiencing the world, where girls will tend to understand the world by going within themselves. With viewpoints this different, should we be surprised that different types of reading appeal to boys?

I'm sorry I fell asleep during reading today. I remember when I was just a little kid and you used to get mad at me when I didn't fall asleep during bedtime reading. Now I wish every book came with a pillow.

When a boy is three years old, the basic interaction he is likely to have with books is bedtime reading. There he is, lying on his back 


\section{4:1 Spring 2007}

with a pillow under his head. Someone he loves is sitting beside him reading to him. What is the purpose of this activity one might ask? What is the hidden goal? Of course, he is supposed to be asleep by the time the story is done or in the best case scenario well before it is done. No wonder that within a few years, (if he has been trained well) he will nod off during reading time. Sleeping in the classroom setting or even worse, in the library, will most certainly land him in trouble.

The scenario I presented is indicative of a major change children experience in reading. Reading goes from being a communal, low stress, enjoyable experience to something they are expected to do independently and at a specified level of proficiency. This major shift happens sometime around age seven or eight for most children. Add to that the fact that boys' brains develop slower than girls'. Girls' brains reach peak size at age $11^{1 / 2}$; boys' brains don't reach their full adult size until about three years later (Ripley, 2005). Should we be surprised that one out of three boys is in a remedial reading program by the time they are in the third grade (Hannaford, 1995)? Boys are being penalized for a lag in brain development that, one, is no reflection on their intelligence, and, two, will disappear in a few years. In the meantime, though, they are pressured to do things that are developmentally inappropriate for them and learn that reading is something meant to be difficult and unpleasant, an attitude they are likely to carry with them for the rest of their lives.

The sad truth is that adults pressure boys to read for no good reason. Pushing children to read harder, longer, and higher quality books, however that is defined, will not make them readers. The only thing that will is reading in volume. According to Stephen (2004) it is a matter of practice. Given that, lower level reading is actually better for children, especially those who struggle with reading, because they are more likely to read more if the exercise is easier, more enjoyable, and most significantly, their choice.

Teaching kids to be avid readers is what will make them good readers.

I'm sorry for being such a bad reader, but I wasn't always a bad reader, remember? When I was four I was a great reader, and I have the super ball to prove it. I got the super ball for reading fifteen books for the public library's summer reading program. Back then it was okay for you to read the words while I looked at the pictures. If I was four years old now I'd still be a great reader. Can we have a holiday where I get to be four again? Then I'd show you how great a reader I can be.

Most boys love reading when they are three years old. We have seen what happens to so many boy readers by the time they are teenagers. What is most sad is that we had all the answers when a boy was three, and we simply stopped doing the things that made reading attractive. We took away the pictures, we turned them away from nonfiction (do you remember those huge truck books we loved so much?), but mostly, we stopped reading to boys. When they turned seven, we thought we were doing them a favor when we insisted that they now read to us. It can be said that in effect for many boys that is punishing a boy for learning to read. What we all know now is that it is also very ineffective and often debilitating. Better we continue to read to them.

Reading to boys exposes them to vocabulary, grammar, narrative flow, sentence structure, and story structure, and at the same time it is fun. It reminds boys of the last time many of them liked reading. Never stop reading to boys of any age, even when they are ninety or more because it is most likely they will listen to a story told. As Stephen (2004) writes listening to a story read aloud has many of the same effects of reading a story yourself.

\section{Conclusion}

In my career as a teacher and a librarian, I have heard a great deal from boys who struggle to read. For all their usual volume, you have to listen hard to hear their desperate voices when they talk about reading. For too long, we have talked at boys about reading. It is time to listen, because we now see the devastating effects that reading problems have on our young men. Most of us accept that boys do not read as much or as well, on average, as girls, but do we really see the effects? Gurian (2001) writes that boys fail in school at twice the rate of girls and that perhaps is one of the main reasons why Colleges today are sixty percent female. A study published in the Journal of $A b$ normal Child Psychology (Maughan et al 2003) reported "robust links between severe and persistent reading problems and increased risk for depressed mood" in seven year old boys who participated in the study. When we know that boys, many of them reluctant readers, drop out of school earlier and more frequently than girls and that they are more likely to be identified as special learners with behaviour, attitude, and literacy skills issues, (What Me Read No Way 2004), parents and educators need to be very concerned and proactive in encouraging boys to read and continuing to read.

One must ask what is being done in schools to attract boys to read and write. If boys do not read well, the study argues they are at risk for depression. We know for a fact that learning to read and to continue to read is an important life skill that paves the way for success in so many areas of life. The fact that more boys are identified as special learners and more boys drop out of school than girls mainly because 
TEACHING \& LEARNING

they cannot read or do not want to read. That should be a warning to everyone who cares about children and their potential.

\section{References}

Gurian, M. (2001). Boys and Girls Learn Differently!: A Guide for Teachers and Parents. (San Francisco, CA: Josse-Bass, p 56-58

Hannaford, Carla (1995). Smart Moves: Why Learning is Not All in Your Head. Arlington, VA: Great Ocean Publishers, p.94.

Krashen, Stephen (2004). The Power of Reading. (Westport, CT: Libraries Unlimited, p.116 and pg 77-81

Maughan, Barbara, Rowe, Richard, Rolf Loeber, and Magda Stouthamer-Loeber. (2003). "Reading Problems and Depressed Mood." Journal of Abnormal Child Psychology April: p.219

Pomerantz, Eva, Rydell-Altermatt, E.
Saxon, Jill (2002). "Making the Grade but pressed Mood." Journal of Abnormal Child Psychology April: p.219

Pomerantz, Eva, Rydell-Altermatt, E. Saxon, Jill (2002)." Making the Grade but Feeling Distressed: Gender Differences in Academic Performance and Internal Distress." Journal of Educational Psychology. 396-404.

Ripley, Amanda (2005). "Who Says a Woman Can't Be Einstein?" Time (March 7) p.55.

Ontario Ministry of Education (2004) What Me Read? NoWay! Queens Printer, Toronto

Looking for suggestions for Books for Boys over nine, try Michael Sullivan's website at www.geocities.com/talestoldtall and Jon Scieszks's website at www.guys read.com
4:1 Spring 2007

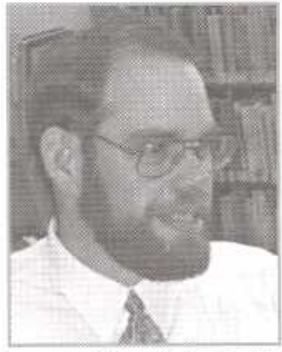

M i c h a e l

Sulliva n

(Bachelors of Arts in

$\mathrm{H}$ is tory, $\mathrm{H}$ a r v a $\mathrm{rd}$ C o 11 e g e , 1989; Masters of Library

Science, Simmons College, 1999) is the author of Connecting Boys With Books: What Libraries Can Do (ALA Editions, 2003), The Fundamentals of Children's Service (ALA Editions, 2005), and Escapade Johnson and Mayhem at Mount Moosilauke (Big Guy Books, 2006). He has spoken widely on the topic of boys and reading, and is currently an adjunct faculty member at Simmons College Graduate School of Library and Information Science in Boston, MA and Plymouth State University in Plymouth, NH.

\section{Call for Papers and A change is in the wind}

A reminder that issue $4: 2$ Awill focus on Action Research. To submit an article, summary of an in school or board wide project or a book review or WEB site review please send the submission

to Nancy.Schoeberle@brocku.ca. The deadline is April $30^{\text {th }}$. A number of excellent submissions have been received, however due to interest we will extend a short window of opportunity until May $15^{\text {th }} 2007$.

Issue 4:3 focuses on Arts in Education. Deadline for submissions is July $30^{\text {th }} 2007$.

Issue 5:1 focuses on how school boards and thus principals and classroom teachers handle issues and concerns about violence in schools and communities. Deadline for submissions is September $30^{\text {th }} 2007$
Submissions must be proof read, and almost camera ready. A.P.A. style preferred. Articles should not exceed 2,500-3000 words. References should be accurate and appropriate but not extensive. Articles that present a concise overview of the literature or research and bring to the reader an applied component are viewed favorably by our panel of reader/ adjudicators. All articles are subject to editorial changes.

\section{A change is in the wind}

Given recent severe budget restraints and increased production costs, members of the Brock Golden Horseshoe Education Consortium have been struggling with how to appropriately produce and deliver Teaching and Learning. The very minimal subscription rate of $\$ 15: 00$ barely covers the cost of shipping and post- age for subscribers, let alone printing, formatting and editing costs. For the past four years consortium members have purchased bulk copies for their teachers, staff and students and as a result have received in return very favorable production end costs. It is in this way that we have been able to ship copies at no cost to other Faculties of Education and School Boards throughout the country. There are changes in the wind. The Consortium is investigating a variety of ways and means of funding, producing and delivering Teaching and Learning. Suggestions include revised financial support budgets, increased subscription fees, advertising and marketing tools, a new delivery format, in-house rotational editing services, on - line publishing sources, and / or WEB based or intranet delivery methods. Any decision will be announced as soon as it is made. 